\title{
definition of patent
}

\author{
Yeni Susanti \\ 165100114 \\ Fakultas Komputer, 448757272 \\ yenisusanti.student@umitrai.ac.id
}

\begin{abstract}
Inventor ideas poured into a specific problem solving activity in the field of technology can be in the form of a product or process, or a product or process improvement and development.

Simple Patent Rights

Namely, every invention in the form of a product or device that is new and has practical utility values due to its shape, configuration, construction or component can obtain legal protection in the form of a simple patent.
\end{abstract}

Keywords: why do you need a patent

\section{A. INTRODUCTION}

Discuss about i cloud system definition of patent is an exclusive granted by the State to the Inventor for the results of his Invention in the field of technology, which carries out the Invasion himself or gives his consent to other parties to carry it out, and have inventor a person who alone or several people who jointly implement an idea poured into an activity that produces an invention And have Simple Patent Rights Namely, every invention in the form of a product or device that is new and has practical utility values due to its shape, configuration, construction or component can obtain legal protection in the form of a simple patent.

Why do you need patent rights? If we have a unique expertise / product that is financially valuable 
then it should be registered at the Directorate General of Intellectual Property Rights of the Ministry of Law and Human Rights of the Republic of Indonesia to obtain Patent Rights, so that it is not hijacked by others without protection of said intellectual property. So if our patent rights are hijacked or imitated by other people, we can be prosecuted legally.

\section{B. CONCLUSION}

Conclusions from this material exclusive rights granted by the State to Inventors for the results of their Inventions in the field of technology, and having inventors, and possessing simple patents of inventions in the form of new products or tools and having practical use values due to their shape, configuration, construction or components. simple patent form why do you need patents because if we have a unique expertise / product that is financially valuable

\section{ACKNOWLEDGEMENT}

University Of Indonesia

University Of Mitra

Indonesia

Telkom University

University Of Mellbourne

Saitama University 
Bandar Lampung," J. Inform., Vol. 13, No. 1, Pp. 90-98, 2014.

[4] Putra, Arie Setya. "2018 Artikel Struktur Data, Audit Dan Jaringan Komputer." (2018).

[5] Putra, A. S. (2018, July 17). Paperplain Fundamental Create Application With Borland Delphi 7.0 University Of Mitra Indonesia. Retrieved From Osf.Io/Pbrn9.

\section{REFERENCE (Based ISO 690 )}

A. S. Putra And O. M. Febriani, "Knowledge Management Online Application In Pdam Lampung Province," In Prosiding International Conference On Information Technology And Business (Icitb), 2018, Pp. 181-187.

[2] A. S. Putra, O. M. Febriani, And B. Bachry, "Implementasi Genetic Fuzzy System Untuk Mengidentifikasi Hasil Curian Kendaraan Bermotor Di Polda Lampung," J. Sist. Inf. Dan Manaj. Basis Data, Vol. 1, No. 1, Pp. 21-30, 2018.

[3] O. M. Febriani And A. S. Putra, "Sistem Informasi Monitoring Inventori Barang Pada Balai Riset Standardisasi Industri

\section{E. REFERENCE (Based APA $)$}

Putra, A. S., Aryanti, D. R., \& Hartati, I. (2018, November). Metode SAW (Simple Additive Weighting) sebagai Sistem Pendukung Keputusan Guru Berprestasi (Studi Kasus: SMK Global Surya). In Prosiding Seminar Nasional Darmajaya (Vol. 1, No. 1, pp. 85-97).

Sari, D. P., Febriani, O. M., \& Putra, A. S. (2018, November). Perancangan Sistem Informasi SDM Berprestasi pada SD Global Surya. In Prosiding Seminar Nasional Darmajaya (Vol. 1, No. 1, pp. 289-294).

Putra, A. S. (2018). Paperplain: Execution Fundamental Create Application With Borland Delphi 7.0 University Of Mitra Indonesia.

Putra, A. S., Sukri, H., \& Zuhri, K. Sistem Monitoring Realtime Jaringan 
Irigasi Desa (JIDES) Dengan Konsep Jaringan Sensor Nirkabel. IJEIS (Indonesian Journal of Electronics and Instrumentation Systems), 8(2), 221232.

Darmawan, A., Yuliawati, D., Marcella, O., \& Firmandala, R. (2016). Sistem Absensi dan Pelaporan Berbasis Fingerprint dan SMS Gateway. EXPLORE, 7(1).

Febriani, O. M., Wahyuni, T., \& Yusuf, S. (2017). DESIGN OF WEBSITE-BASED INFORMATION SYSTEM FOR EDOCUMENT ADMINISTRASI IN THE COMMUNITY SERVICE UNIT (A Case Study at Rajabasa District). INTERNATIONAL JOURNAL OF COMPUTERS \& TECHNOLOGY, 16(7), 7010-7020.

Febriani, O. M., \& Wahyuni, T. (2017, October). PERANCANGAN SISTEM E-DOCUMENT ADMINISTRASI LOGBOOK PENELITIAN PADA UNIT LAYANAN DI BANDAR LAMPUNG. In Prosiding Seminar Nasional Darmajaya (Vol. 1, No. 1, pp. 187-194).

Febriani, O. M., \& Permadi, A. B. (2017). Implementasi Sistem Aplikasi Data Bimbingan dan Pelanggaran Siswa pada Sekolah Menengah Atas di Lampung Tengah dengan Metode Analisis dan Desain Sistem Terdistribusi (SSAD). EXPERT, 7(1).

Febriani, O. M., \& Ambarwati, L. (2015). PERANCANGAN APLIKASI PENGOLAHAN DATA PENJUALAN UKM KELANTING

\section{KHAS TELO DESA SIDOHARJO KECAMATAN JATI AGUNG KABUPATEN LAMPUNG SELATAN. Jurnal Teknologi Informasi dan Bisnis Pengabdian Masyarakat Darmajaya, 1(1), 77-95.}

Febriani, O. M. (2015). Rancang Bangun Aplikasi Ecommercemenggunakan Freewebstore pada UKM Kelanting di Desa Sidoharjo Lampung Selatan. Prosiding Sembistek 2014, 1(02), 446-458. 